\title{
Copeptin and its potential role in diagnosis and prognosis of various diseases
}

\author{
Lidija Dobša*1 ${ }^{* 1}$ Kido Cullen Edozien² \\ ${ }^{1}$ Health Institution Varaždin County, Medical Biochemistry Laboratory, Varaždin, Croatia \\ ${ }^{2}$ Mater Dei Hospital, Msida, Malta \\ *Corresponding author: lidijadobsa@gmail.com
}

\begin{abstract}
The need for faster diagnosis, more accurate prognostic assessment and treatment decisions in various diseases has lead to the investigations of new biomarkers. The hope is that this new biomarkers will enable early decision making in clinical practice. Arginine vasopressin (AVP) is one of the main hormones of the hypothalamic-pituitary-adrenal axis. Its main stimulus for secretion is hyperosmolarity, but AVP system is also stimulated by exposure of the body to endogenous stress. Reliable measurement of AVP concentration is difficult because it is subject to preanalytical and analytical errors. It is therefore not used in clinical practice. Copeptin, a 39-aminoacid glycopeptide, is a C-terminal part of the precursor pre-provasopressin (pre-proAVP). Activation of AVP system stimulates copeptin secretion into the circulation from the posterior pituitary gland in equimolar amounts with AVP. Therefore, copeptin directly reflects AVP concentration and can be used as surrogate biomarker of AVP secretion. Even mild to moderate stress situations contribute to release of copeptin. These reasons have lead to a handful of research on copeptin in various diseases. This review summarizes the current achievements in the research of copeptin as a diagnostic and prognostic marker and also discusses its association in different disease processes.
\end{abstract}

Key words: human copeptin; endogenous stress; diagnostic accuracy; prognosis

\section{Introduction}

Copeptin, a 39-aminoacid glycopeptide is a C-terminal part of pre-provasopressin (pre-proAVP). Pre-proAVP is a precursor protein which consists of a signal peptide, arginine vasopressin (AVP), neurophysin II and copeptin (1-3). These components are separated during axon transport from the cell body to the axon terminals in the posterior pituitary gland (3). On the path from the hypothalamus to the pituitary gland, copeptin and neurophysin II act as carrier proteins of AVP. Copeptin is stored in the neurohypophyseal vesicles together with AVP and neurophysin II until they are secreted (4). Schematic presentation of copeptin generation and maturation is shown in Figure 1. Copeptin also has a very important role in the proteolysis of pre-proAVP, but its main role in the circulation is still unknown $(3,6)$. Slow degradation of copeptin in humans hints that this peptide may not have any significant function in the circulation (6). Copeptin is cosynthesized with AVP and is found in equimolar amounts with AVP in the circulation of healthy and critically ill subjects $(7,8)$. Thus copeptin mirrors AVP concentration and can be used as a replacement biomarker of AVP release $(6,7)$.

For certain diseases, diagnosis and prognosis can still be very demanding and time-consuming. This is why new biomarkers are needed to aid clinicians in making faster treatment decisions and more accurate prognostic assessment. To be of practical value, a new biomarker needs to provide quantitative information that is both reliable and reproducible. Moreover, the measurement of a biomarker should be easy, rapid and inexpensive to perform. Therefore, copeptin has been proposed as a prognostic marker in different illnesses and disorders 


\begin{tabular}{|c|c|}
\hline $\begin{array}{l}\text { Synthesis of pre-pro-AVP in the } \\
\text { magnocellular nuclei of the } \\
\text { hypothalamus }\end{array}$ & \\
\hline Cleavage of the signal peptide & \\
\hline $\begin{array}{l}\text { Pro-AVP folds, placing AVP into } \\
\text { a binding pocket of neurophysin } \\
\text { II, protecting it from proteolysis } \\
\text { and promoting high-density } \\
\text { packing in neurosecretory } \\
\text { vesicles }\end{array}$ & \\
\hline $\begin{array}{l}\text { Formation of seven disulfide } \\
\text { bonds within neurophysin II } \\
\text { and one within AVP; } \\
\text { glycosylation of copeptin }\end{array}$ & \\
\hline $\begin{array}{l}\text { Pro-AVP is packaged into } \\
\text { neurosecretory granules }\end{array}$ & \\
\hline $\begin{array}{l}\text { Cleavage of pro-AVP that splits } \\
\text { off AVP }\end{array}$ & $\begin{array}{l}\text { During axonal transport from } \\
\text { the hypothalamic nuclei to the }\end{array}$ \\
\hline Cleavage that separates & neutrohypophysis \\
\hline neurophysın II trom copeptın & $\begin{array}{l}\text { Processing is complete at the } \\
\text { level of the neurohypophysis }\end{array}$ \\
\hline
\end{tabular}

Figure 1. Schematic presentation of copeptin generation and maturation (5).

where it may help in early detection and diagnostic accuracy. The purpose of this review is to summarize a handful of research done on copeptin and to discuss its role as a biological marker in the diagnosis and prognosis of various diseases such as acute myocardial infarction (AMI), heart failure, hyponatremia, sepsis, septic shock, infections of lower respiratory tract, acute dyspnea, vasodilatory shock, diabetes insipidus, autosomal dominant polycystic kidney disease (ADPKD), diabetes mellitus, metabolic syndrome, intracerebral hemorrhage, ischemic stroke and head injury.

\section{Copeptin in circulation}

Normal values of copeptin in healthy volunteers range between 1.70-11.25 pmol/L $(6,9,10)$. Copeptin also shows minimal intra-individual variations (11). In healthy people, a $28 \mathrm{~h}$ water deprivation leads to a twofold increase in concentration of copeptin, while infusion of hypotonic saline induces a 2-3-fold decrease of copeptin concentration (11). Copeptin concentration are lower in women when compared to men, but there is no significant difference in copeptin rise between men and women with changes in osmolality or volume status $(3,12,13)$. Renal function also influences copeptin concentration in healthy men and this is not noticed in healthy women (12). Copeptin has not being found to correlate with age or estimated glomerular filtration rate in healthy subjects, except in patients with AMI where copeptin concentration correlates with age and estimated glomerular filtration rate $(9,12,13)$. In advanced and acute heart failure the rise in copeptin concentration goes from $20 \mathrm{pmol} / \mathrm{L}$ to $45 \mathrm{pmol} / \mathrm{L}$. In terms of life threatening conditions, such as severe sepsis, septic shock, hemorrhagic shock, ischemic stroke and AMI, copeptin increases to concentrations above $100 \mathrm{pmol} / \mathrm{L}$. On the opposite sphere, copeptin decreases in patients with diabetes insipidus, hyponatremia and other conditions associated with reduced AVP concentration (13). It is still however unknown how copeptin is removed from the circulation. It is assumed that it is partially cleared through the kidneys because it is detectable in urine (7).

\section{Function of AVP}

AVP is a vasoactive neuropituitary hormone. It is one of the main hormones of the hypothalamicpituitary-adrenal axis and its primary function is water regulation and homeostasis of electrolytes. The main stimulus for AVP release is hyperosmolarity. Hypotension, hypoxia, acidosis, infection, insulin-induced hypoglycemia, pain, nausea, vomiting, certain drugs and other non-specific causes of stress can also increase concentration of AVP in the circulation $(3,7)$.

AVP binds to 3 different receptors, V1a, V1b and V2 receptor. They are classified into three subtypes based on their intracellular transduction mechanisms. The V1a and V1b receptors are associated with phosphoinositol turnover, while the V2 receptor activates adenylate cyclase (14). The V1a receptor is widely expressed and mediates AVPs prothrombotic and vasoconstrictor effects. Thus, AVP agonists are used in treating bleeding and hypotensive disorders (15-17). Through V1a receptor 
AVP also mediates liver glycogenolysis $(16,17)$. The V1b receptor is expressed in the pituitary gland and pancreas $(15,16)$. Through this receptor AVP stimulates the release of adrenocorticotropic hormone. Adrenocorticotropic hormone activates the hypothalamic-pituitary-adrenal axis and thus mediates a response to stress. Insulin and glucagon secretion are mediated via $\mathrm{V} 1 \mathrm{~b}$ receptor as well $(16,17)$. The V2 receptor is expressed in the renal collecting ducts and through those receptors the antidiuretic effect of AVP is mediated $(15,16)$. Pharmacological blockade of $\mathrm{V} 2$ receptor has been used to treat hyponatremia and heart failure $(16,17)$.

\section{Measurement of AVP and copeptin}

Reliable measurement of plasma AVP concentration is difficult and is subject to preanalytical and analytical errors. Such difficulties stem from fact that AVP is unstable due to its short half-life of 24 min. To add to this problem, more than $90 \%$ of AVP in the circulation is bound to platelets, thus making accurate measurements very difficult $(3,6,18,19)$. Incomplete removal of platelets from plasma samples or prolonged storage of unprocessed blood samples can lead to falsely elevated values of AVP. AVP is also unstable in isolated plasma and serum even when it is stored at $-20{ }^{\circ} \mathrm{C}$ $(6,13)$. The small size of AVP also challenges detection by sandwich immunoassays and therefore requires the use of less sensitive competitive immunoassays (13). All the above mentioned reasons contribute to the absence of routine AVP use in clinical practice (6).

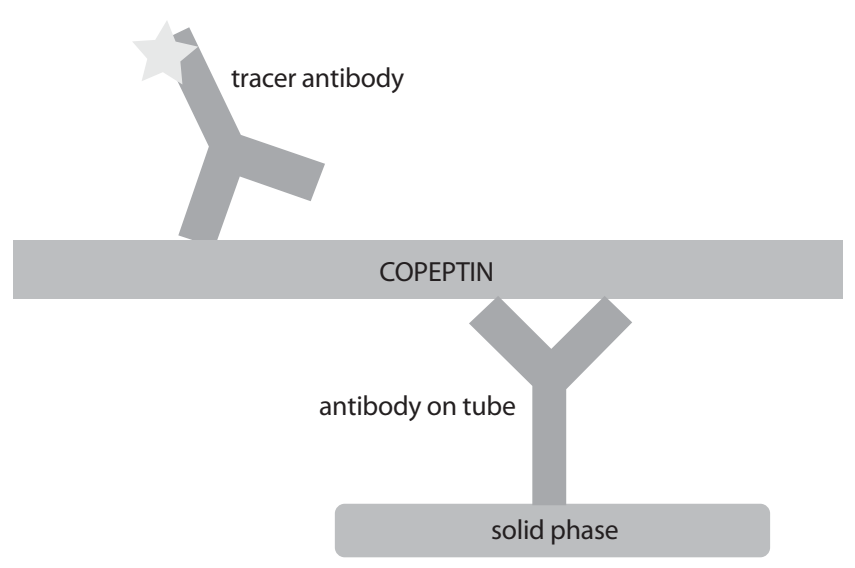

Figure 2. Scheme of assay for the measurement of copeptin.

Unlike AVP, copeptin is stable in EDTA plasma for up to 14 days at room temperature, while in citrate and heparin plasma copeptin is stable for 7 days (19). Its detection doesn't require extraction or other complex preanalytical steps (13). It can easily be measured ex vivo by manual or fully automated chemiluminescence assays as a replacement biomarker for unstable AVP $(1,20,21)$. Scheme of assay for the measurement of copeptin is shown in Figure 2. The assay requires minimal serum or plasma volume and the overall time for completing the analysis is between 20 and 30 minutes (13). Based on these facts, copeptin is suitable for routine measurements as an alternative to AVP (6). Some of the methodology characteristics for copeptin and AVP assays are summarized in Table 1.

TABLE 1. Some of the methodology characteristics for copeptin and AVP assays $(21,22)$.

\begin{tabular}{cc}
\hline Copeptin & AVP \\
\hline sandwich immunoassay & radioimmunoassy \\
sensitivity $-2.25 \mathrm{pmol} / \mathrm{L}$ & sensitivity $-0.5 \mathrm{pg} / \mathrm{ml}(0.2 \mu \mathrm{U} / \mathrm{ml})$ \\
$\mathrm{CV}<20 \%$ & $\mathrm{CV}-17 \%$ \\
precise measurement in a range of $2.25-1215 \mathrm{pmol} / \mathrm{L}$ & sample volume $-1 \mathrm{ml}$ or less \\
assay linearity at analyte dilutions up to $1: 32$ & complex preanalytic procedures including peptide extraction \\
\hline
\end{tabular}




\section{Copeptin as a diagnostic and prognostic marker}

In stressful situations such as illness, the relationship between plasma osmolality and AVP is lost because AVP with corticotropin-releasing hormone (CRH) leads to the production of adrenocorticotropic hormone (ACTH) and cortisol. Serum cortisol is proportional to stress levels, and by reflecting stress levels, cortisol predicts prognostic outcome in different diseases. However, cortisol is influenced by strong circadian rhythm and its measurement as a free hormone is demanding. These characteristics of cortisol place copeptin as a more reliable hormone for determination of stress levels. Of note, even mild to moderate stress situations contribute to the copeptin release. In recent years copeptin has being studied as a diagnostic and prognostic biomarker in various diseases (Table 2). Of mention are acute myocardial infarction, heart failure, acute exacerbation of chronic obstructive pulmonary disease, lower respiratory tract infections, acute dyspnea, sepsis, hemorrhagic and septic shock, diabetes mellitus, metabolic syndrome, hyponatremia, vasodilatory shock, diabetes insipidus, autosomal dominant polycystic kidney disease (ADPKD), intracerebral hemorrhage, ischemic stroke and traumatic brain injury $(8,20)$. The data on diagnostic accuracy of copeptin in different disorders are shown in Table 3.

TABLE 2. Overview of the most important references on copeptin.

\begin{tabular}{|c|c|c|c|}
\hline Article; year & No. patients & Aim & Conclusion \\
\hline \multicolumn{4}{|c|}{ Acute miocardial infarction } \\
\hline $\begin{array}{l}\text { Gu et al. } \\
(25) ; 2011 .\end{array}$ & $\begin{array}{l}145 \text { patients undergoing } \\
\text { successful primary PCI } \\
\text { for a first ST-elevation } \\
\text { AMI presenting within } \\
12 \text { h of symptom onset }\end{array}$ & $\begin{array}{l}\text { To compare the temporal release } \\
\text { pattern of copeptin with CK-MB, } \\
\text { cTnT and hs-cTnT in patients } \\
\text { with ST-elevation AMI. }\end{array}$ & $\begin{array}{l}\text { Copeptin is elevated in the early hours } \\
\text { after the onset of an ST-elevation AMI } \\
\text { when CK-MB and CTnT are still low. }\end{array}$ \\
\hline $\begin{array}{l}\text { Ray et al. } \\
(24) ; 2012 .\end{array}$ & $\begin{array}{l}451 \text { patient with a previous } \\
\text { history of CAD and } \\
\text { negative cTn at admission }\end{array}$ & $\begin{array}{l}\text { To evaluate the additional value } \\
\text { of copeptin to conventional cTn } \\
\text { for a rapid ruling out of AMI in } \\
\text { patients with acute chest pain } \\
\text { and a previous history of CAD. }\end{array}$ & $\begin{array}{c}\text { In ED triage of patients with acute chest } \\
\text { pain suggestive of a non-ST-segment } \\
\text { elevation AMI and a previous history of } \\
\text { CAD, the combination of copeptin and } \\
\text { CTnl allows clinicians to rule out AMI on } \\
\text { presentation, with an NPV of } 98 \% \text {. }\end{array}$ \\
\hline $\begin{array}{l}\text { von Haehling } \\
\text { et al. (26); } 2012 .\end{array}$ & $\begin{array}{l}2,700 \text { patients }(74.1 \% \\
\text { male; } \mathrm{AMI}, \mathrm{N}=1316 ; \text { stable } \\
\text { angina pectoris, } \mathrm{N}=1384)\end{array}$ & $\begin{array}{l}\text { To investigate the prognostic } \\
\text { value of copeptin with regard } \\
\text { to mortality and morbidity in } \\
\text { patients with symptomatic CAD. }\end{array}$ & $\begin{array}{l}\text { Copeptin may help in the prediction } \\
\text { of major adverse cardiovascular events } \\
\text { in patients with symptomatic CAD. }\end{array}$ \\
\hline $\begin{array}{l}\text { Reichlin et al. } \\
\text { (27); } 2009 .\end{array}$ & $\begin{array}{l}487 \text { patients presenting } \\
\text { to the ED with symptoms } \\
\text { suggestive of AMI }\end{array}$ & $\begin{array}{l}\text { To examine the incremental value of } \\
\text { copeptin for rapid rule out of AMI. }\end{array}$ & $\begin{array}{l}\text { The additional use of copeptin seems } \\
\text { to allow a rapid and reliable rule out } \\
\text { of AMI already at presentation and } \\
\text { may thereby obviate the need for } \\
\text { prolonged monitoring and serial blood } \\
\text { sampling in the majority of patients. }\end{array}$ \\
\hline $\begin{array}{l}\text { Meune et al. } \\
(28) ; 2011 .\end{array}$ & $\begin{array}{l}58 \text { consecutive patients } \\
\text { - ACS in } 30 \text { patients (AMI } \\
\text { in } 13 \text { patients, unstable } \\
\text { angina in } 17 \text { patients) } \\
\text { and nonacute coronary } \\
\text { syndrome in } 28 \text { patients }\end{array}$ & $\begin{array}{l}\text { To examine the possible } \\
\text { incremental value of copeptin } \\
\text { in the detection of ACS. }\end{array}$ & $\begin{array}{l}\text { A dual marker strategy that combines } \\
\text { hs-cTnT with copeptin increases slightly } \\
\text { the detection of ACS at admission. }\end{array}$ \\
\hline $\begin{array}{l}\text { Lotze et al. } \\
\text { (29); } 2011 .\end{array}$ & $\begin{array}{l}142 \text { consecutive patients } \\
\text { (mean age } 71.2 \pm 13.5 \\
\text { years, } 76 \text { men) }\end{array}$ & $\begin{array}{l}\text { To test the diagnostic performance of } \\
\text { the hs-cTnT combined with copeptin } \\
\text { measurement for early exclusion of AMI. }\end{array}$ & $\begin{array}{l}\text { A single determination of hs-cTnT and } \\
\text { copeptin may enable early and accurate } \\
\text { exclusion of AMI in one third of patients, } \\
\text { even in an ED of a general hospital. }\end{array}$ \\
\hline
\end{tabular}




\begin{tabular}{|c|c|c|}
\hline Article; year & No. patients & Aim \\
\hline $\begin{array}{l}\text { Keller et al. } \\
(30) ; 2010 .\end{array}$ & 1386 patients ( $66.4 \%$ male) & $\begin{array}{l}\text { To test whether determination } \\
\text { of copeptin adds diagnostic } \\
\text { information to cardiac troponin in } \\
\text { early evaluation of patients with } \\
\text { suspected myocardial infarction. }\end{array}$ \\
\hline
\end{tabular}

\begin{tabular}{|c|c|c|}
\hline $\begin{array}{l}\text { Hernández- } \\
\text {-Romero et al. } \\
\text { (23); } 2012 .\end{array}$ & $\begin{array}{l}122 \text { non-STEACS patients } \\
\text { without raised TnT, } 33 \\
\text { disease controls and } \\
43 \text { healthy controls }\end{array}$ & $\begin{array}{l}\text { To investigate whether the use of } \\
\text { hs-cTnT or copeptin together with } \\
\text { the association to the classical clinical } \\
\text { and electrocardiographic parameters } \\
\text { might help to the better stratification } \\
\text { and managements as well as in the } \\
\text { prognosis of patients with non-STEACS }\end{array}$ \\
\hline
\end{tabular}

\section{Conclusion}

In triage of chest pain patients, determination of copeptin in addition to Tn improves diagnostic performance, especially early after CPO. Combined determination of Tn and copeptin provides a remarkable NPV virtually independent of CPO time and therefore aids in early and safe rule-out of AMI.

hs-cTnT levels increased in non-STEACS were predictive of adverse events and could be important for recommending an invasive management. A predictive role of copeptin out of the first hours from admission cannot be confirmed.

\begin{tabular}{cc}
\hline & \\
\hline Voors et al. & $\begin{array}{c}224 \text { patients with } \\
\text { symptoms of HF or a } \\
\text { (16); 2009. }\end{array}$ \\
left ventricular ejection \\
fraction $<0.35$ after AM
\end{tabular}

\section{Heart failure}

To compare the prognostic value of a copeptin with BNP and

NT-proBNP on death or a composite cardiovascular endpoint in patients who developed HF after AMI.
Copeptin is a strong marker for mortality and morbidity in patients with HF after AMI. In this population, the predictive value of copeptin is even stronger than BNP and NT-proBNP.

Among elderly patients with symptoms of $\mathrm{HF}$, elevated concentrations of copeptin and the combination of elevated concentrations of copeptin and NT-proBNP were associated with increased risk of all-cause mortality.

In pharmacologically unstable chronic HF patients, ba seline values and follow-up measures of copeptin, midregional proadrenomedullin, C-terminal endothelin-1 precursor fragment, MR-proANP and BNP were equally predictive of all-cause mortality.

Increased levels of copeptin are linked to excess mortality, and this link is maintained irrespective of the clinical signs of severity of the disease. Copeptin is superior to BNP or NT-proBNP in this study, but the markers seem to be closely related.

\section{Hyponatremia}

Neuhold et al.

(33); 2008.

HF (NYHA functional class I to IV) to the BNP and NT-proBNP.

Copeptin measurement reliably identifies patients with primary polydipsia but has limited utility in the differential diagnosis of other hyponatremic disorders. In contrast, the copeptin to $\mathrm{U}-\mathrm{Na}$ ratio is superior to the reference standard in discriminating volume-depleted from

normovolemic hyponatremic disorders.

To evaluate the diagnostic potential of copeptin as a new marker in the differential diagnosis of hyponatremia.
Fenske et al. (34); 2009.
106 consecutive
hyponatremic patient 


\begin{tabular}{|c|c|c|c|}
\hline Article; year & No. patients & Aim & Conclusion \\
\hline $\begin{array}{l}\text { Nigro et al. } \\
\text { (35); } 2011 .\end{array}$ & $\begin{array}{l}545 \text { patients with suspected } \\
\text { LRTI and CAP; } 509 \text { patients } \\
\text { with a final diagnosis of } \\
\text { an ischaemic }(\mathrm{N}=362) \\
\text { or haemorrhagic stroke } \\
(\mathrm{N}=40) \text { or transient } \\
\text { ischaemic attack }(\mathrm{N}=107)\end{array}$ & $\begin{array}{l}\text { To assess copeptin concentrations } \\
\text { in sick patients with serum sodium } \\
\text { imbalance of different aetiology } \\
\text { on admission to the ED. }\end{array}$ & $\begin{array}{l}\text { Plasma copeptin level appears to } \\
\text { add very little information to the } \\
\text { work up of sodium imbalance in } \\
\text { this cohort of medical inpatients. } \\
\text { It is likely that the nonosmotic } \\
\text { "stress"-stimulus in acute hospitalised } \\
\text { patients is a major confounder and } \\
\text { overrules the osmotic stimulus. }\end{array}$ \\
\hline
\end{tabular}

Sepsis and septic shock

Jochberger et 10 patients with infection,

al. (36); 2009 22 with severe sepsis, and

28 with septic shock
To compare the course of AVP and copeptin plasma concentrations between patients with infection, severe sepsis, and septic shock.

Severe sepsis induced a stronger AVP

response than infection without systemic inflammation. The lack of a difference

in AVP plasma concentrations between patients with and without shock indicates that the AVP system does not function normally in severe sepsis.

\begin{tabular}{ccc}
\hline & Infections of lower respiratory tract \\
\hline $\begin{array}{c}\text { Seligman et } \\
\text { al. }(15) ; 2011 .\end{array}$ & 71 patients with VAP & $\begin{array}{r}\text { To compare the predictive value } \\
\text { of different biomarkers including } \\
\text { copeptin for mortality in VAP. }\end{array}$ \\
\hline $\begin{array}{c}\text { Boeck et al. } \\
(38) ; 2012 .\end{array}$ & 101 patients & $\begin{array}{l}\text { To investigate the predictive value of } \\
\text { the SOFA score and copeptin in VAP. }\end{array}$
\end{tabular}

Müller et al.

(39); 2007.

545 consecutive patients with LRTI and

50 healthy controls
To investigate circulating levels and the prognostic use of copeptin for the severity and outcome in patients with LRTI.

The biomarkers procalcitonin MR-proANP, and copeptin can predict mortality in VAP, as can the SOFA score.

The predictive value of serial-measured SOFA significantly exceeds those of single SOFA and copeptin measurements. Serial SOFA scores accurately predict outcome in VAP.

Copeptin levels are increased with increasing severity of LRTI namely in patients with CAP and unfavorable outcome. Copeptin levels, as a novel biomarker, might be a useful tool in the risk stratification of patients with LRTI.

Copeptin serum levels are higher in patients without antibiotic pre-treatment compared with those with antibiotic pre-treatment. Copeptin serum levels increase with an increasing severity of CAP in patients without, but not in patients with, antibiotic pre-treatment. (40); 2009. pre-treatment, 285 without
antibiotic pre-treatment)

To evaluate the influence of antibiotic pre-treatment on copeptin levels in CAP.
Copeptin levels increase progressively with the severity of sepsis and are independent predictors of mortality in VAP.

Seligman et
al. (42); 2008.

Masiá et al.

(43); 2007.

173 patients

Stolz et al.

(44); 2007.
167 patients with AECOPD
To investigate the correlation of copeptin with the severity of septic status in patients with VAP and to analyze the usefulness of copeptin as a predictor of mortality in VAP.
Copeptin and MR-proANP may be used to predict prognosis in patients with CAP. mortality in patients with CAP.
Copeptin is suggested as a prognostic marker for short-term and long-term prognoses in patients with AECOPD requiring hospitalization.
CRP and procalcitonin as potential prognostic parameters for in-hospital and long-term outcomes in patients with $A E C O P D$ requiring hospitalization. 


\begin{tabular}{|c|c|c|c|}
\hline Article; year & No. patients & Aim & Conclusion \\
\hline \multicolumn{4}{|c|}{ Acute dyspnea } \\
\hline $\begin{array}{l}\text { Potocki et al. } \\
\text { (45); } 2010 .\end{array}$ & $\begin{array}{l}287 \text { patients with } \\
\text { acute dyspnea }\end{array}$ & $\begin{array}{l}\text { To investigate the prognostic } \\
\text { value of copeptin alone and } \\
\text { combined to NT-proBNP in } \\
\text { patients with acute dyspnea. }\end{array}$ & $\begin{array}{l}\text { Copeptin is a new promising } \\
\text { prognostic marker for short-term } \\
\text { mortality independently and } \\
\text { additive to natriuretic peptide levels } \\
\text { in patients with acute dyspnea. }\end{array}$ \\
\hline \multicolumn{4}{|c|}{ Vasodilatory shock } \\
\hline $\begin{array}{l}\text { Torgersen et } \\
\text { al. }(46) ; 2010 .\end{array}$ & $\begin{array}{l}50 \text { critically ill patients } \\
\text { with advanced } \\
\text { vasodilatory shock }\end{array}$ & $\begin{array}{l}\text { To evaluate plasma copeptin levels } \\
\text { before and during exogenous AVP } \\
\text { infusion and to determine the } \\
\text { value of copeptin levels before AVP } \\
\text { therapy to predict complications } \\
\text { during AVP therapy and outcome } \\
\text { in vasodilatory shock. }\end{array}$ & $\begin{array}{l}\text { Plasma copeptin levels are elevated in } \\
\text { patients with advanced vasodilatory } \\
\text { shock. During exogenous AVP } \\
\text { therapy, copeptin levels decrease, } \\
\text { suggesting suppression of the } \\
\text { endogenous AVP system. }\end{array}$ \\
\hline
\end{tabular}

\section{Diabetes insipidus}

\begin{tabular}{|c|c|c|c|}
\hline $\begin{array}{l}\text { Katan et al. } \\
(2) ; 2007 .\end{array}$ & 38 patients & $\begin{array}{l}\text { To study the value of copeptin levels } \\
\text { in the diagnosis of diabetes insipidus } \\
\text { during insulin-induced hypoglycemia. }\end{array}$ & $\begin{array}{l}\text { Copeptin measurement may be used } \\
\text { to assess posterior together with } \\
\text { anterior pituitary function during } \\
\text { insulin-induced hypoglycemia. }\end{array}$ \\
\hline \multicolumn{4}{|c|}{ Kidneys disease } \\
\hline $\begin{array}{l}\text { Meijer et al. } \\
\text { (47); } 2011 .\end{array}$ & 102 ADPKD patients & $\begin{array}{l}\text { To determine whether endogenous } \\
\text { AVP concentration is associated with } \\
\text { disease severity in patients with ADPKD. }\end{array}$ & $\begin{array}{l}\text { On cross-sectional analysis, copeptin } \\
\text { is associated with disease severity } \\
\text { in ADPKD patients, supporting the } \\
\text { results of experimental studies that } \\
\text { suggest that AVP antagonists have } \\
\text { a renoprotective effect in ADPKD } \\
\text { and offering a good prospect for } \\
\text { clinical studies with these agents. }\end{array}$ \\
\hline
\end{tabular}

\section{Diabetes mellitus and metabolic syndrome} Enhörning et $\quad 4742$ individuals (mean age
al. (11); 2010.
To examine the association of increasing quartiles of copeptin (lowest quartile as reference) with prevalent DM at baseline, insulin resistance and incident DM on long-term follow-up.
Elevated copeptin predicts increased risk for DM independently of established clinical risk factors, including fasting glucose and insulin. These findings could have implications for risk assessment, novel antidiabetic treatments, and metabolic side effects from AVP system modulation.

Plasma copeptin is cross-sectionally associated with measures of insulin resistance and MetS.

Copeptin independently predicts

DM and abdominal obesity but not the cluster of MetS. al. (49); 2012. Reinvestigation and end points: 2064 individuals
To investigate whether plasma copeptin is associated with measures of insulin resistance and presence of MetS.

To test whether elevated copeptin level is associated with later development of the MetS, its individual components and microalbuminuria.

\section{Central nervous system diseases}

To investigate the ability of copeptin

106 healthy controls, 106 patients with acute severe traumatic brain injury to predict 1-year outcome in patients with traumatic brain injury.

Copeptin is a useful, complementary tool to predict functional outcome and mortality 1 year after traumatic brain injury.

Copeptin is a new prognostic marker in patients with an ICH. If this finding can be confirmed in larger studies, copeptin might be an additional valuable tool for risk stratification and decision-making in the acute phase of $\mathrm{ICH}$. 


\begin{tabular}{|c|c|c|c|}
\hline Article; year & No. patients & Aim & Conclusion \\
\hline $\begin{array}{l}\text { Zhang et al. } \\
\text { (51); } 2012 .\end{array}$ & $\begin{array}{l}50 \text { healthy controls, } \\
89 \text { patients with acute } \\
\text { spontaneous basal } \\
\text { ganglia hemorrhage }\end{array}$ & $\begin{array}{l}\text { To evaluate the relation of plasma } \\
\text { copeptin levels to long-term } \\
\text { outcome and early neurological } \\
\text { deterioration after } \mathrm{ICH} \text {. }\end{array}$ & $\begin{array}{l}\text { Increased plasma copeptin level } \\
\text { is an independent prognostic } \\
\text { marker of 1-year mortality, 1-year } \\
\text { unfavorable outcome and early } \\
\text { neurological deterioration after ICH. }\end{array}$ \\
\hline $\begin{array}{l}\text { Dong et al. } \\
(52) ; 2011 .\end{array}$ & $\begin{array}{l}30 \text { healthy controls, } 86 \\
\text { patients with acute ICH }\end{array}$ & $\begin{array}{l}\text { To investigate changes in plasma } \\
\text { copeptin levels in patients during the } \\
\text { initial 7-day period after ICH and also } \\
\text { determine whether copeptin is an } \\
\text { independent prognostic marker of } \\
\text { mortality in a group of ICH patients. }\end{array}$ & $\begin{array}{l}\text { Increased plasma copeptin level is } \\
\text { associated with hematoma volume } \\
\text { and an independent prognostic } \\
\text { marker of mortality after ICH. }\end{array}$ \\
\hline $\begin{array}{l}\text { Zhu et al. (53); } \\
2011 .\end{array}$ & $\begin{array}{c}303 \text { patients with an initial } \\
\text { diagnosis of aneurysmal } \\
\text { SAH }\end{array}$ & $\begin{array}{l}\text { To investigate the ability of copeptin } \\
\text { to predict the disease outcome and } \\
\text { cerebrovasospasm in the patients with } \\
\text { SAH. }\end{array}$ & $\begin{array}{c}\text { Copeptin level is a useful, complementary } \\
\text { tool to predict functional outcome and } \\
\text { mortality after SAH. }\end{array}$ \\
\hline \multicolumn{4}{|c|}{$\begin{array}{l}\mathrm{PCI} \text { - percutaneous coronary intervention; CAD - coronary artery disease; ED - emergency department; ACS - acute coronary syndrome; CPO - } \\
\text { chest pain onset; non-STEACS - ACS without ST-segment elevation; HF - heart failure; DM - diabetes mellitus; U-Na - Na levels in urine; LRTI - lower } \\
\text { respiratory tract infection; SOFA - Sequential Organ Failure Assessment; MR-proANP - midregional proatrial natriuretic peptide; AECOPD - acute } \\
\text { exacerbation of chronic obstructive pulmonary disease; AA - African-Americans; NHW - non-Hispanic whites; MetS - metabolic syndrome; SAH - } \\
\text { aneurysmal subarachnoid hemorrhage }\end{array}$} \\
\hline
\end{tabular}

TABLE 3. Diagnostic accuracy of copeptin in different disorders.

\begin{tabular}{|c|c|}
\hline Article year & Result \\
\hline \multicolumn{2}{|r|}{ Acute miocardial infarction } \\
\hline $\begin{array}{l}\text { Ray et al. } \\
(24) ; 2012 .\end{array}$ & $\begin{array}{l}\text { A negative cTnT combined with a copeptin value lower than } 10.7 \mathrm{pmol} / \mathrm{L} \text { at presentation was able to rule out AMI } \\
\text { with a NPV of } 98 \%(95 \% \mathrm{Cl}, 95-99 \%) .\end{array}$ \\
\hline $\begin{array}{l}\text { von Haehling et } \\
\text { al. (26); } 2012 .\end{array}$ & $\begin{array}{l}\text { Calculated AUC for copeptin of } 0.703(95 \% \mathrm{Cl}: 0.681-0.725) \text { for the composite endpoint after three months } \\
\text { (myocardial reinfarction, stroke, all-cause death), and } 0.770(95 \% \mathrm{Cl}: 0.736-0.803) \text { for all-cause death. A cutoff } \\
\text { value of } 21.6 \mathrm{pmol} / \mathrm{L} \text { for the composite endpoint yielded a sensitivity of } 56.3 \% \text { and a specificity of } 78.6 \% \text {. }\end{array}$ \\
\hline $\begin{array}{l}\text { Reichlin et al. } \\
\text { (27); } 2009 .\end{array}$ & $\begin{array}{l}\text { Copeptin levels were significantly higher in AMI patients compared with those having other diagnoses (median } \\
20.8 \mathrm{pmol} / \mathrm{L} \text { vs. } 6.0 \mathrm{pmol} / \mathrm{L}, \mathrm{P}<0.001) \text {. The AUC for troponin T and copeptin at initial presentation was } 0.97 \\
(95 \% \mathrm{Cl}: 0.95-0.98) \text {, and for troponin T alone } 0.86(95 \% \mathrm{Cl}: 0.80-0.92)(\mathrm{P}<0.001) \text {. A copeptin level }<14 \mathrm{pmol} / \mathrm{L} \text { in } \\
\text { combination with a troponin } \mathrm{T} \leq 0.01 \mu \mathrm{g} / \mathrm{L} \text { correctly ruled out } \mathrm{AMI} \text { with a sensitivity of } 98.8 \% \text { and a NPV of } 99.7 \% \text {. }\end{array}$ \\
\hline $\begin{array}{l}\text { Meune et al. } \\
\text { (28); } 2011 .\end{array}$ & $\begin{array}{l}\text { The combination of copeptin with hs-cTnT for determination of patients with ACS on admission provided a NPV } \\
\text { of } 82.6 \% \text {. The AUC was } 0.90 \text { for hs-cTnT measured on admission, and } 0.94 \text { if repeated at } 3 \text { hours and } 6 \text { hours or } \\
\text { combined with copeptin measurement at admission (non-significant difference). }\end{array}$ \\
\hline $\begin{array}{l}\text { Lotze et al. } \\
(29) ; 2011 .\end{array}$ & $\begin{array}{c}\text { A hs-cTnT level of }<0.014 \mu \mathrm{g} / \mathrm{L} \text { in combination with copeptin }<14 \mathrm{pmol} / \mathrm{L} \text { at initial presentation ruled out AMI in } \\
31.7 \% \text { of patients, each with a sensitivity and NPV of } 100 \% \text {. }\end{array}$ \\
\hline $\begin{array}{l}\text { Keller et al. } \\
(30) ; 2010 .\end{array}$ & $\begin{array}{c}\text { Combined measurement of copeptin and TnT on admission improved the c-statistic from } 0.84 \text { for TnT alone to } \\
0.93 \text { in the overall population and from } 0.77 \text { to } 0.9 \text { in patients presenting within } 3 \mathrm{~h} \text { after CPO }(\mathrm{P}<0.001) \text {. The } \\
\text { combination of copeptin with a conventional TnT provided a NPV of } 92.4 \% \text {. }\end{array}$ \\
\hline \multicolumn{2}{|r|}{ Heart failure } \\
\hline $\begin{array}{l}\text { Voors et al. } \\
(16) ; 2009 .\end{array}$ & $\begin{array}{l}\text { Copeptin (AUC 0.81) is a stronger predictor of mortality compared with BNP (AUC 0.66; P = } 0.006 \text { vs. copeptin) } \\
\text { and NT-proBNP (AUC } 0.67 ; P=0.002 \text { vs. copeptin). }\end{array}$ \\
\hline $\begin{array}{l}\text { Alehagen et al. } \\
\qquad(31) ; 2011 .\end{array}$ & $\begin{array}{l}\text { In a ROC analysis of cardiovascular mortality using the } 10 \text {-year follow-up period, the AUC increased from } 0.70 \\
\text { to } 0.76(95 \% \mathrm{Cl}, 0.71-0.82) \text { by adding copeptin concentration to clinical examination variables and NT-proBNP } \\
\text { concentration. }\end{array}$ \\
\hline $\begin{array}{l}\text { Neuhold et al. } \\
\text { (33); } 2008 .\end{array}$ & $\begin{array}{l}\text { The AUC with respect to 2-year all-cause mortality in HF patients was } 0.711 \text { for BNP and } 0.711 \text { for copeptin. The } \\
\text { predictive power increased to an AUC of } 0.744 \text { if both variables were added in one model. }\end{array}$ \\
\hline
\end{tabular}




\begin{tabular}{cc}
\hline Article year & Result \\
\hline & Hyponatremia \\
\hline $\begin{array}{c}\text { Fenske et al. } \\
\text { (34); } 2009 .\end{array}$ & $\begin{array}{r}\text { The copeptin to U-Na ratio exhibited a good diagnostic utility identifying SIADH with an AUC of } 0.88 \text { (95\% } \\
\end{array}$ \\
\hline
\end{tabular}

\section{Infections of lower respiratory tract}

\begin{tabular}{|c|c|}
\hline $\begin{array}{l}\text { Seligman et al. } \\
\text { (15); } 2011 .\end{array}$ & $\begin{array}{l}\text { Copeptin accuracy in predicting mortality in VAP: on the day of VAP onset (sensitivity } 0.69 \text {, specificity } 0.69 \text {, AUC } \\
0.70 \text { ( } 95 \% \text { Cl: } 0.57-0.82) \text {, PPV } 0.56, \text { NPV } 0.80, \text { LR+ 2.23, LR- } 0.45) \text {; on the fourth day (sensitivity } 0.80 \text {, specificity } 0.60 \text {, } \\
\text { AUC } 0.72(95 \% \text { Cl: } 0.59-0.84) \text {, PPV } 0.53 \text {, NPV } 0.84 \text {, LR+ 2.00, LR- } 0.33)\end{array}$ \\
\hline $\begin{array}{l}\text { Boeck et al. (38); } \\
2012 .\end{array}$ & $\begin{array}{c}\text { The AUC of copeptin at VAP onset was } 0.67 \text { ( } 95 \% \mathrm{Cl}: 0.53-0.81) \text {, and that of mean copeptin was } 0.70(95 \% \mathrm{Cl} \text { : } \\
0.57-0.84) \text {. The AUC values of the combination SOFA-copeptin at VAP onset }(0.73 ; 95 \% \mathrm{Cl}: 0.60-0.87) \text { and of the } \\
\text { combination SOFA mean-copeptin mean }(0.89 ; 95 \% \mathrm{Cl}: 0.80-0.99) \text { were not superior as compared with the AUC } \\
\text { value of SOFA. }\end{array}$ \\
\hline $\begin{array}{l}\text { Müller et al. (39); } \\
2007 .\end{array}$ & $\begin{array}{l}\text { In patients with CAP, the AUC of copeptin to predict survival was } 0.68(0.63-0.73) \text {. To differentiate CAP from other } \\
\text { LRTIs, copeptin had an AUC of } 0.73(0.69-0.76) \text {. Thereby, with the optimal cut-off of } 22.7 \mathrm{pmol} / \mathrm{L} \text {, sensitivity was } \\
66.5 \% \text { and specificity was } 68.7 \% \text {. To achieve } 90 \% \text { sensitivity, the cut-off for copeptin was } 9 \mathrm{pmol} / \mathrm{L} \text { with specificity } \\
\text { of } 39 \% \text {. }\end{array}$ \\
\hline
\end{tabular}

Seligman et al. The AUC for copeptin to predict mortality in VAP patients on the day VAP was suspected, was 0.70 . For a (42); 2008 . threshold of $64.8 \mathrm{pmol} / \mathrm{L}$, the sensitivity was 0.69 and the specificity was 0.69 . The AUC for copeptin on the fourth (42), 2008. day of treatment was 0.72 . Using a cutoff level of $43.0 \mathrm{pmol} / \mathrm{L}$, the sensitivity was 0.80 and the specificity was 0.60 .

\begin{tabular}{|c|c|}
\hline \multicolumn{2}{|r|}{ Acute dyspnea } \\
\hline $\begin{array}{c}\text { Potocki et al. } \\
\text { (45); } 2010 .\end{array}$ & $\begin{array}{l}\text { The AUC for copeptin to predict } 30 \text {-day mortality in patients with acute dyspnea was } 0.83(95 \% \mathrm{Cl}: 0.76-0.90) \text {, } \\
\text { with an optimal cut-point of } 59 \mathrm{pmol} / \mathrm{L} \text {. Copeptin had a significantly higher AUC compared with } \mathrm{BNP}(\mathrm{P}= \\
0.002) \text { but not compared to NT-proBNP }(\mathrm{P}=0.21) \text {. In patients with ADHF the AUC for copeptin was } 0.84(95 \% \mathrm{Cl} \text { : } \\
0.76-0.92) \text {, (copeptin vs. NT-proBNP P }=0.098 \text {; copeptin vs. BNP P < 0.001). }\end{array}$ \\
\hline
\end{tabular}

\section{Vasodilatory shock}

Torgersen et al. Copeptin levels at randomization predicted the occurrence of ischemic skin lesions (AUC 0.73; $P=0.04)$, a fall in (46); 2010. $\quad$ platelet count (AUC 0.75; $P=0.01)$ during AVP and intensive care unit mortality $(A \cup C 0.67 ; P=0.04)$.

\section{Diabetes insipidus}

A basal copeptin level less than $2.59 \mathrm{pmol} / \mathrm{L}$ had $89 \%$ sensitivity and $76 \%$ specificity to detect diabetes insipidus.

Katan et al. A stimulated copeptin level 45 min after insulin injection less than 4.75 pmol/L had $100 \%$ sensitivity and $100 \%$

(2); 2007. specificity to detect diabetes insipidus. Copeptin levels 30 and 90 min after insulin injection had an AUC to detect diabetes insipidus of 0.94 and 0.98 , respectively.

\section{Diabetes mellitus and metabolic syndrome}

In subjects free of DM at baseline, the AUC increased from 0.694 to $0.710(P=0.08)$ when copeptin was added

Enhörning et al. to the personal model and from 0.832 to $0.841(P=0.007)$ when copeptin was added to the clinical model of
diabetes prediction. In subjects free of IFG at baseline, the AUC increased from 0.663 to $0.713(P=0.03)$ and

(11); 2010 . from 0.783 to $0.805(P=0.04)$ when copeptin was added to the personal model and clinical model for diabetes prediction, respectively.

In multivariable logistic regression analyses that adjusted for age and sex, plasma copeptin levels in the third and

Saleem et al. fourth quartile were significantly associated with a higher odds of having metabolic syndrome: OR of 1.81 ( $P<$

(48); 2009. $\quad 0.001)$ and $1.91(P<0.001)$, respectively. In the subset of participants without diabetes, having a plasma copeptin

level in the third or fourth quartile was significantly associated with the presence of metabolic syndrome (OR

$1.83, \mathrm{P}<0.001 ; \mathrm{OR} 1.82, \mathrm{P}=0.001$, respectively) after adjustment for age and sex.

After additional adjustment for all the MetS components at baseline, increasing copeptin quartiles predicted

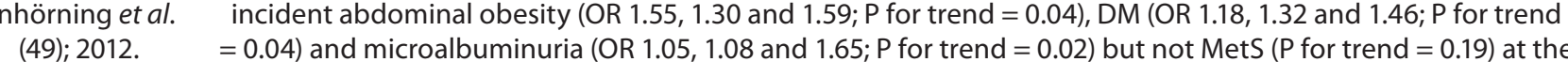
reexamination.

\section{Central nervous system diseases}

Yu et al.

(17); 2012.

AUC identified that a baseline plasma copeptin level $>540.9 \mathrm{pg} / \mathrm{mL}$ predicted 1-year unfavorable outcome of patients with $75.0 \%$ sensitivity and $91.4 .0 \%$ specificity (AUC $0.905 ; 95 \% \mathrm{Cl}: 0.833-0.953$ ) and that a baseline plasma copeptin level $>503.6 \mathrm{pg} / \mathrm{mL}$ predicted 1-year mortality of patients with $90.3 \%$ sensitivity and $77.3 \%$ specificity (AUC 0.909; 95\% Cl: 0.837-0.956). 


\begin{tabular}{|c|c|}
\hline Article year & Result \\
\hline $\begin{array}{l}\text { Zweifel et al. } \\
\text { (50); } 2010 .\end{array}$ & $\begin{array}{l}\text { For the prediction of death, } \mathrm{ROC} \text { analysis revealed an AUC for copeptin of } 0.88(95 \% \mathrm{Cl}: 0.75-1.00) \text {. The predictive } \\
\text { value of the copeptin concentration was thus similar to that of GCS (AUC } 0.82(95 \% \mathrm{Cl} ; 0.59-1.00) \mathrm{P}=0.53) \text {, of the } \\
\text { ICH Score (AUC 0.89, }(95 \% \mathrm{Cl}: 0.76-1.00), \mathrm{P}=0.94) \text { and the ICH Grading Scale (AUC } 0.86(95 \% \mathrm{Cl}: 0.69-1.00), \mathrm{P}=0.81) \text {. }\end{array}$ \\
\hline $\begin{array}{l}\text { Zhang et al. (51); } \\
2012 .\end{array}$ & $\begin{array}{c}\text { A multivariate analyses selected NIHSS score }(\mathrm{OR}=1.219 ; 95 \% \mathrm{Cl}: 1.148-1.498 ; \mathrm{P}<0.001) \text { and baseline plasma } \\
\text { copeptin level }(\mathrm{OR}=1.138 ; 95 \% \mathrm{Cl}: 1.063-1.345 ; \mathrm{P}<0.001) \text { as the independent predictors for } 1 \text {-year mortality. } \\
\text { A multivariate analyses selected } \mathrm{NIHSS} \text { score }(\mathrm{OR}=1.385 ; 95 \% \mathrm{Cl}: 1.211-1.680 ; \mathrm{P}<0.001) \text { and baseline plasma } \\
\text { copeptin level }(\mathrm{OR}=1.191 ; 95 \% \mathrm{Cl}: 1.102-1.323 ; \mathrm{P}<0.001) \text { as the independent predictors for } 1 \text {-year unfavorable } \\
\text { outcome. A multivariate analyses selected } \mathrm{NIHSS} \text { score }(\mathrm{OR}=1.321 ; 95 \% \mathrm{Cl}: 1.140-1.430 ; \mathrm{P}<0.001) \text { and baseline } \\
\text { plasma copeptin level }(\mathrm{OR}=1.217 ; 95 \% \mathrm{Cl}: 1.139-1.398 ; \mathrm{P}<0.001) \text { as the independent predictors for early } \\
\text { neurological deterioration. }\end{array}$ \\
\hline $\begin{array}{l}\text { Dong et al. } \\
\text { (52); } 2011 .\end{array}$ & $\begin{array}{c}\text { A multivariate analysis showed that plasma copeptin level was an independent predictor for } 1 \text {-week mortality } \\
\text { (OR }=1.013 ; 95 \% \mathrm{Cl}: 1.003-1.023 ; \mathrm{P}=0.009) \text { and positively associated with hematoma volume }(\mathrm{t}=6.616, \mathrm{P}<0.001) \text {. } \\
\text { The AUC identified that a baseline plasma copeptin level }>577.5 \mathrm{pg} / \mathrm{mL} \text { predicted } 1 \text {-week mortality with } 87.5 \% \\
\text { sensitivity and } 72.2 \% \text { specificity }(\mathrm{AUC}=0.873 ; 95 \% \mathrm{Cl}: 0.784-0.935)\end{array}$ \\
\hline $\begin{array}{l}\text { Zhu et al. } \\
\text { (53); } 2011 .\end{array}$ & $\begin{array}{c}\text { A cutoff value of } 20.5 \mathrm{pmol} / \mathrm{L} \text { for copeptin predicted } 1 \text {-year mortality with } 92.8 \% \text { sensitivity and } 70.1 \% \text { specificity } \\
\text { (AUC } 0.868 \pm 0.036 ; \mathrm{P}<0.001 \text { ), a cutoff value of } 28.7 \mathrm{pmol} / \mathrm{L} \text { predicted in-hospital mortality with } 78.1 \% \text { sensitivity } \\
\text { and } 89.7 \% \text { specificity (AUC } 0.868 \pm 0.042 ; \mathrm{P}<0.001 \text { ), a cutoff value of } 23.4 \mathrm{pmol} / \mathrm{L} \text { predicted cerebrovasospasm } \\
\text { with } 69.2 \% \text { sensitivity and } 84.9 \% \text { specificity (AUC } 0.792 \pm 0.027 ; \mathrm{P}<0.001 \text { ) and a cutoff value of } 23.8 \mathrm{pmol} / \mathrm{L} \\
\text { predicted 1-year poor neurologic outcome with } 82.2 \% \text { sensitivity and } 79.8 \% \text { specificity }(A U C, 0.860 \pm 0.026 ; \mathrm{P}< \\
0.001 \text { ). }\end{array}$ \\
\hline \multicolumn{2}{|c|}{$\begin{array}{l}\mathrm{Cl} \text { - confidence interval; AUC - area under the curve; P - predictive value; CPO - chest pain onset; ROC - receiver operating characteristic curve; HF } \\
\text { - heart failure; U-Na - Na levels in urine; LR+- positive likelihood ratio; LR- - negative likelihood ratio; SOFA - Sequential Organ Failure Assessment; } \\
\text { LRTI - lower respiratory tract infection; ADHF - acute decompensated heart failure; DM - diabetes mellitus; IFG - impaired fasting glucose; OR - } \\
\text { odds ratio; MetS - metabolic syndrome; GCS - Glasgow Coma Scale score; NIHSS - National Institutes of Health Stroke Scale }\end{array}$} \\
\hline
\end{tabular}

\section{Copeptin in acute myocardial infarction}

Acute myocardial infarction (AMI) is a major cause of death in industrialized countries. Its prevalence in third-world countries is also steadily rising. Therefore, it is extremely important to ensure early detection and diagnostic accuracy. These abilities will aid rapid interventions in AMI and prevent premature discharge of unrecognized AMI patients from the emergency department (13). The most important methods in the diagnosis of $\mathrm{AMI}$ are electrocardiography (ECG) and determination of serum cardiac troponin $\mathrm{T}$ (cTnT) concentration, which complement clinical assessment. Cardiac Tn is superior to other biomarkers available for AMI diagnosis, including myoglobin, $M B$ fraction of creatine kinase (CK-MB), myeloperoxidase and heart fatty acid-binding protein (23). Despite these methods and biomarkers, the exclusion of AMI is still demanding. ECG is of little help in the exclusion of AMI because one quarter to one third of patients with AMI show no significant ECG changes in the presence of ongoing acute cardiac ischemia. However, ECG is necessary for identification of patients with ST-segment elevation (24). Conventional cardiac biomarkers, such as CK-MB and $\mathrm{TnT}$, are unable to aid in rapid exclusion of $\mathrm{AMI}$ in patients presenting early in the hospital with symptoms suggestive for AMI. This is due to the fact that their concentrations do not increase during the first few hours of AMI (25). Therefore, the exclusion of $\mathrm{AMI}$ requires monitoring of patients between a 6 to 9 hour period and serial blood sampling for measurement of cTnT concentration $(24,26,27)$.

In order to increase the accuracy for detection of AMI, a highly sensitive cardiac troponin T (hs-cTnT) has been developed, which allows measurement of concentrations that are 10 times lower than the previous ones. This assay allows greater accuracy and earlier detection of AMI $(28,29)$. However, despite its ability for earlier diagnosis of $A M I$, there is still a "troponin-blind" interval after the onset of chest pain still due to delayed troponin release 
(29). A use of this assay enables detection of myocardial injury due to a broad spectrum of pathologies which includes myocardial ischemic and myocyte physiologic remodeling. It increases the number of positive tests on admission as compared to the less sensitive assays which complicates triage and management of patients with chest pain (13).

If the organism is exposed to endogenous stress such as AMI, this activates the AVP system and copeptin is excreted into circulation independent of necrosis of cardiac cells (28). Also, inadequate filling of the left ventricle caused by AMI stimulates cardiac baroreceptors or causes direct damage to baroreceptors which subsequently leads to AVP and copeptin secretion from the posterior pituitary gland (13). After the onset of chest pain copeptin is elevated within 3-4 hours, reaching a peak value in the first day $(26,29)$. During the second day they slowly start to decrease reaching a plateau after 3-5 days (29). From the pathophysiological aspect, decreasing concentration of copeptin just a day after myocardial ischemia may indicate adjustment to neurohumoral stress by activation of AVP system after AMI (29). A decrease in copeptin concentration may also be due to the cessation or at least a reduction of chest pain after the onset of AMI, or they may as well be an inter-play of both reasons (27). Copeptin rises at a time when other biomarkers are still undetectable $(25,27)$. CK-MB, TnT and hs-cTnT concentrations reach peak values after more than 14 hours and return to their normal values slower (25). Copeptin is more sensitive than cTnT and myoglobin within the first 3 hours of AMI detection. The sensitivity of copeptin is $75.2 \%$ (cutoff $>9.8 \mathrm{pmol} / \mathrm{L}$ ), cTnT 43\% (cutoff $>0.03$ $\mu \mathrm{g} / \mathrm{L}$ ) and myoglobin $62.3 \%$ (cutoff $>107 \mathrm{ng} / \mathrm{mL}$ ) (30). However, in the final exclusion of AMI, copeptin is not able to replace cTnT, but only enables making earlier decisions in clinical practice (30). The combination of copeptin and cTn, compared with only cTn, improves diagnostic accuracy of AMI reaching a sensitivity of $85.1 \%$ and a negative predictive value (NPV) of $92.4 \%$ within 3 hours from the onset of chest pain. The highest sensitivity and NPV were achieved with $9.8 \mathrm{pmol} / \mathrm{L}$ as the cutoff representing the 95th percentile (30). Reichlin et al. reported even a greater sensitivity and NPV using both markers in exclusion of AMI. A copeptin concentration $<14 \mathrm{pmol} / \mathrm{L}$ in combination with a TnT $\leq 0.01 \mu \mathrm{g} / \mathrm{L}$ rules out $\mathrm{AMl}$ at presentation with a sensitivity of $98.8 \%$ and a NPV of $99.7 \%$ (27). Therefore, such combination of biomarkers would enable fast and accurate exclusion of AMI at an early stage of presentation without the need for serial blood sampling (24). This strategy of using more biomarkers (cTnT or hs-cTnT for detection and quantification of myocardial necrosis, and copeptin for quantification of endogenous stress) to assess the outcome after AMI has an advantage because it includes various pathological pathways and may be of prognostic significance $(14,23,25$, 27).

In a recent study Lotze et al. reported a positive correlation between hs-cTnT and copeptin at the time of initial AMI presentation ( $r=0.41 ; P<0.001)$. Cut-off value of $0.014 \mu \mathrm{g} / \mathrm{L}$ for hs-cTnT can be used for fast exclusion of AMI with a sensitivity of $92.3 \%$, specificity of $53.5 \%$, positive predictive value (PPV) of $16.7 \%$ and NPV of $98.6 \%$. The corresponding values for copeptin are $69.2 \%, 47.3 \%, 11.7 \%$ and 93.9\%, respectively. Cut-off value of $0.014 \mu \mathrm{g} / \mathrm{L}$ for hs-cTnT in combination with a copeptin value of < $14 \mathrm{pmol} / \mathrm{L}$ at admission exclude AMI with a sensitivity of $100 \%$, specificity of $34.9 \%$, PPV of $13.4 \%$ and NPV of $100 \%$, indicating that this combination of biomarkers has a higher diagnostic accuracy than use of only hs-cTnT or copeptin. By measuring hs-cTnT with copeptin, AMI could be ruled out with a NPV of $100 \%$ in one third of patients who have symptoms which indicate to AMI (29). In addition, Meune et al. reported that the combination of hscTnT and copeptin at admission compared with use of only hs-cTnT increased detection of acute coronary syndrome (ACS) on the level which is similar to serial measurement of hs-cTnT. The combination of hs-cTnT and copeptin at admission excludes ACS with a sensitivity of $86.7 \%$ and NPV of $82.6 \%$ (hs-cTnT value of $0.014 \mu \mathrm{g} / \mathrm{L}$ is the 99 th percentile of the assay; cut-off value of copeptin is 14 $\mathrm{pmol} / \mathrm{L})$. The sensitivity of only hs-cTnT measured at admission was $73.3 \%$ and NPV was $76.5 \%$, while sensitivity and NPV of hs-cTnT measured after 3 hours were $83.3 \%$ and $83.9 \%$, respectively (28). 
Copeptin concentration is significantly higher in patients with suspected ACS with final diagnosis of AMI compared to patients with suspected ACS with a different final diagnosis. These diagnoses include unstable angina and other cardiac and non-cardiac causes of chest pain (25). Patients with unstable angina have similar copeptin concentration like patients with other causes of chest pain (27). Therefore, ischemia, as long as not accompanied by necrosis (e.g. unstable angina), does not cause higher secretion of copeptin than other causes of chest pain. Also, copeptin cannot discriminate patients with unstable angina from patients with non ischemic chest pain (27).

\section{Copeptin and heart failure}

Currently there are several neurohormones which are used as biomarkers for diagnosis, prognosis and clinical decision in chronic heart failure. The Btype natriuretic peptide (BNP) and N-terminal proBNP (NT-proBNP) are the most common. They are released in the circulation when cardiac stretching occurs and they are powerful prognostic biomarkers of heart failure outcome $(19,31)$. But despite these biomarkers, it is considered that heart failure is not detected in up to $50 \%$ of patients, so diagnosis of this disease remains a major challenge (31). Therefore, scientific research has lately been directed towards finding new biomarkers that can improve the diagnosis and prognosis of heart failure.

It is noticed that AVP concentration is increased in patients with chronic heart failure $(16,19,31)$. Since AVP secretion is partially stimulated in response to a high osmolality, there are still unanswered questions as to why we find an increase of AVP in patients with heart failure who generally have a lower osmolality $(16,31)$. There are several possible explanations for this increase. The release of AVP in heart failure is mainly stimulated by reduced cardiac output, and in turn insufficient filling of arteries leads to carotid sinus and aortic arch baroreceptor activation. It seems that in heart failure, AVP secretion caused by osmolarity stimulus is overridden by the non-osmolarity stimulus, which leads to hypo-osmolality. Some studies showed that hyponatremia, which is often present in patients with heart failure, might also stimulate the release of AVP. It is also known that angiotensin II increases concentration of AVP. In heart failure angiotensin II is elevated even in the presence of ACE inhibitors $(16,19)$.

AVP serves as a parameter of disease severity and it appears to have a role in the pathology of heart failure as well. AVP by stimulation of V1a receptors increases protein synthesis in myocytes, it stimulates the development of myocardial hypertrophy and decreases heart contractility and also stimulates cardiac fibroblasts, and thus promotes myocardial fibrosis. Increased release of AVP is also associated with increased preload, increased filling pressures and increased afterload (31). High copeptin concentration which reflects rise of AVP in the blood therefore predicts poor prognosis in patients with chronic heart failure $(16,18)$. Copeptin is a good predictor of death or heart failure within 60 days, helping to classify patients into groups of low, medium and high risk. It is also independent of already established conventional risk factors for heart failure $(16,20)$. Copeptin is not only important for short-term prognosis but is also important in identifying patients with long-term risk. Increased copeptin concentration in elderly patients with symptoms of heart failure is associated with increased risk of mortality after a follow-up of 13 years (20).

Copeptin reflects different pathological pathways that lead to a deterioration of heart failure than BNP or NT-proBNP, so when copeptin is combined with BNP or NT-proBNP, predicting disease outcome can be improved (19). Some studies indicate the equal prognostic value of copeptin, BNP and NT-proBNP in predicting mortality, whereas some studies give a better prognostic value to copeptin $(14,16,19,32,33)$. A possible explanation for better prognostic value of copeptin is that BNP and NTproBNP, unlike copeptin, correlate with age and renal function. Also there is large variation in BNP in plasma over time in chronic heart failure. However, the combined measurement of plasma copeptin and NT-proBNP certainly provides more valuable information than the measurement of only one biomarker $(14,16)$. 
Neuhold et al. investigated the predictive ability of copeptin for the entire spectrum of heart failure, including patients with New York Heart Association (NYHA) functional class I to IV. They reported that copeptin at all symptomatic stages of heart failure was independently associated with mortality, and it was the most powerful predictor of death in II and III NYHA class. However, it is noteworthy that for asymptomatic patients (NYHA functional class I) rate of events was too low to ensure information in this cohort. For patients in the most severe stage of heart failure (NYHA functional class IV) copeptin has provided additional independent information, but was inferior to the values of sodium and glomerular filtration (33).

\section{Copeptin and hyponatremia}

Distinguishing patients with syndrome of inappropriate antidiuretic hormone secretion (SIADH) from patients with hyponatremia in clinical practice is a diagnostic challenge. Measuring copeptin concentration is not reliable enough to differentiate these two conditions due to large overlaps in values of copeptin, even though mean values of copeptin are higher in patients with hyponatremia compared to patients with SIADH (34). However, it has been proven that the ratio of copeptin in serum and sodium in urine is diagnostically very useful (34). This ratio can be used in differentiating normovolemic hyponatremia (ratio $\leq 30 \mathrm{pmol} / \mathrm{mmol}$ ) as SIADH, from hypovolemic hyponatremia (ratio $>30 \mathrm{pmol} / \mathrm{mmol}$ ), i.e. in differentiation of inappropriate from appropriate secretion of AVP $(15,34)$.

Higher copeptin concentration is seen in patients with hyponatremia during chronic renal failure compared to patients with gastrointestinal loss. This is probably due to several reasons, such as activation of the AVP system in patients with impaired renal function, abundance of receptors for AVP in renal tubules, and the fact that copeptin is excreted from the body via the kidneys (35). Measuring copeptin concentration in plasma of patients with acute illnesses seems to provide little information about sodium imbalance because copeptin concentration is similar in different etiologies of sodium imbalance. It is worth mentioning that though copeptin concentration may be similar in different etiologies, it may still contribute to understanding the pathophysiology of various causes of hyponatremia (35).

\section{Copeptin, sepsis and septic shock}

AVP and copeptin are also elevated in sepsis and septic shock $(4,6,36)$. Jochberger et al. reported that AVP concentration is higher in patients with sepsis compared to patients with infections without systemic inflammation. AVP secretion can be induced by inflammatory mediators such as interleukin 1, tumor necrosis factor a and several other factors such as acidosis, pain, hypoxia or neuroendocrine stress. These latter factors are also likely to occur in patients with severe sepsis than in patients with infections without systemic inflammation (36). In this study, AVP values did not differ between patients with severe sepsis with shock and those without shock, or between surviving patients and those who didn't survive. In septic shock higher values of AVP are expected because of reduced venous filling as well as arterial hypotension which stimulate the release of AVP. However, during severe sepsis and primarily during septic shock, AVP system is partially dysfunctional and relative AVP deficiency contributes to the inability to establish vascular tone in patients with septic shock. Proposed mechanisms for possible sepsis associated dysfunction of AVP system include autonomic dysfunction of afferent pathways and inadequate production of AVP with consequent depletion of storage in the neuro-hypophysis. In patients with severe sepsis AVP in plasma is associated with serum osmolarity, arterial $\mathrm{pH}$, oxygen partial pressure and arterial lactate, whereas in patients with septic shock AVP is associated only with serum osmolarity (36).

In sepsis and septic shock significantly higher plasma copeptin has been noticed as well. Although there is an excellent correlation between copeptin and AVP in different diseases, their correlation in severe sepsis and septic shock is smaller. The need for continuous veno-venous hemofiltration (CVVHF) worsens the correlation between copeptin and AVP, suggesting that different sieving coefficients may result in diverse amounts of filtered hormone levels during CVVHF. Inflammation can 
also interfere with the relationship between AVP and copeptin (36). Unlike the AVP whose values don't differ in patients with sepsis who survived and those who didn't survive, copeptin is higher in non-survivors compared to survivors $(15,36,37)$. This suggests that copeptin could represent a prognostic biomarker in sepsis $(15,37)$.

\section{Copeptin and infections of lower respiratory tract}

In infections of lower respiratory tract, gas exchange in the lungs causes changes in AVP system (38). Endotoxins and acute phase cytokines (e.g. IL$1 \beta, I L-6, T N F-\alpha)$ which are present during respiratory infections also stimulate the secretion of AVP (39). However, AVP also has an important role in regulation of the hypothalamic-pituitary-adrenal axis through which it mediates its response to stress in diseases (39). Copeptin is cosynthesized with AVP, it is found in equimolar amounts with AVP in the circulation, and therefore copeptin concentration is significantly higher than in healthy individuals. Copeptin concentration was measured in patients with community-acquired pneumonia (CAP), ventilator associated pneumonia (VAP), acute bronchitis and chronic obstructive pulmonary disease (COPD). It was found that in those diseases copeptin concentration increased with the severity of the disease (15,39-42). It has been shown that copeptin is an independent predictor of mortality in VAP $(15,40-42)$. Due to the complexity of AVP effects in VAP, the difference in copeptin concentration according to survival status is small, and therefore cannot be defined with a clear cutoff value. Biomarker that predicts the outcome of a disease should be elevated in that disease compared to healthy individuals, and it must reflect the degree of organ dysfunction and overall health condition. Boeck et al. reported that copeptin fulfills the first two criteria, but lacks considerably in the third criterion. Therefore, its predictive power is lost in the heterogeneous picture of VAP (38).

In CAP copeptin is the only biomarker that is an independent predictor of this disease, and may provide additional information about the severity of disease. Due to its high NPV, copeptin may help in identifying patients with low risk of death. Since it is independent of patient's age, it can be a valuable prognostic factor in young patients with CAP (43). Despite its very good prognostic value, copeptin gives little information about predicting the etiology of CAP because there is considerable overlap in copeptin values between patients with different etiologies of pneumonia (43). Krüger et al. reported that it is clinically important to consider antibiotic therapy for correct interpretation of copeptin concentration as well as concentration of other inflammatory biomarkers in CAP, because patients treated with antibiotics showed significantly lower copeptin values compared to those who didn't take antibiotics before admission to the hospital, which can be explained by reduced circulation damage caused by sepsis (40).

In severe chronic obstructive pulmonary disease (COPD) AVP has a vasoconstrictive effect. At insufficient tissue oxygenation this response makes cardiovascular adaptation easier through elevated AVP concentration. Elevated AVP compensates for insufficient activation of V1 receptors after exposure to ongoing hypoxemia. It is also considered that in pulmonary hypertension AVP creates a negative inotropic effect on the right ventricle and increases pulmonary vasoconstrictive response in endotoxemia. This could link increased AVP and copeptin with poor clinical outcome in COPD (40). Compared with CRP and procalcitonin, copeptin is superior in predicting the course of COPD exacerbation. Elevated copeptin concentration predicts the final outcome in patients with acute exacerbation of COPD and serves as a risk factor for longterm clinical failure, regardless of age, comorbidity, hypoxemia or functional pulmonary disorder (44).

Müller et al. compared copeptin values in various etiologies of lower respiratory tract infections and reported that copeptin concentration in patients with acute bronchitis and acute exacerbation of COPD was significantly higher compared to control group. On further examination it was also discovered that there was no difference in copeptin concentration between acute bronchitis and acute exacerbation of COPD. Also, patients who were diagnosed with CAP had the highest copeptin concentration. Only slightly elevated copeptin concentration in acute bronchitis and acute exacerba- 
tion of COPD compared to control group probably reflects localized infection (39).

\section{Copeptin and acute dyspnea}

The identification of dyspneic patients at the highest risk for adverse outcomes is difficult because acute dyspnea often occurs due to several reasons such as cardiac, pulmonary or inflammatory causes (45). In these patients copeptin secretion is probably connected with three possible mechanisms. Firstly, AVP released in heart failure is mainly driven by inadequate filling of arteries which activates the carotid sinus and aortic arch baroreceptors. Secondly, in severe COPD AVP has vasoconstrictive effect which is induced by hypoxia. Elevated concentration of AVP can compensate for the inadequate regulation of $\mathrm{V} 1$ receptors after exposure to ongoing hypoxemia. Finally, copeptin is significantly elevated in bacterial infection and febrile conditions (45).

Potocki et al. pointed out that copeptin concentration is significantly higher in patients with acute decompensated heart failure (ADHF) compared to patients with other diagnoses responsible for acute dyspnea. Also, in that study, copeptin was significantly higher in patients who did not survive compared to patients who survived at 30 days, regardless of the presence of ADHF. Therefore, copeptin could be a promising prognostic biomarker for short term mortality in patients with acute dyspnea and even more in patients with ADHF. Copeptin is also independent of natriuretic peptides values (45).

\section{Copeptin and vasodilatory shock}

Copeptin concentration in plasma is elevated in patients with severe vasodilatory shock. These elevated copeptin reflects the severity of the disease, a higher incidence of complications and a greater risk of death. AVP is infused in patients with severe vasodilatation with the intention of supplementing a lack of endogenous AVP and reducing the use of potentially high and toxic doses of catecholamine. During therapy with exogenous AVP, copeptin concentration is decreased, suggest- ing the suppression of endogenous AVP system. High copeptin before treatment and the extent of decrease of copeptin during treatment with exogenous AVP is associated with severity of disease and mortality (46).

\section{Copeptin and diabetes insipidus}

AVP is released into the circulation after hypoglycemic stimulus. Insulin-induced hypoglycemia is used as a standardized procedure to assess the integrity of the hypothalamic-pituitary-adrenal axis. In patients with normal pituitary function, insulininduced hypoglycemia leads to a threefold increase of AVP concentration. Since copeptin strongly correlates with AVP, copeptin can separate healthy people from patients with diabetes insipidus. Copeptin concentration measured 45 minutes after injection of insulin has the best sensitivity and specificity for detection of diabetes insipidus. Copeptin has good, but not perfect discriminatory capacity (2).

\section{Copeptin and kidneys disease}

Copeptin is associated with autosomal dominant polycystic kidney disease (ADPKD) as well. ADPKD is the most common hereditary kidney disease which is characterized by progressive cyst formation in both kidneys. AVP binds to V2 receptors in the distal tubules and collecting ducts promoting water absorption and production of CAMP. CAMP plays an important role in the stimulation of cyst growth in the kidney. Since copeptin reflects AVP concentration, measurement of copeptin can provide valuable information about the severity of ADPKD. Higher copeptin concentration is associated with poor renal function, lower effective renal blood flow, larger kidneys and albuminuria. Copeptin is associated with plasma osmolarity, but not with 24-hour urine volume, 24-hour urine osmolarity or fractional excretion of urea. In people with lower glomerular filtration, the fact that copeptin is partly cleared by the kidney probably isn't an explanation for higher concentration of copeptin because increased copeptin concentration would induce a lowering of plasma osmolarity, which would lead to a decrease of copeptin (47). 


\section{Copeptin, diabetes mellitus and metabolic syndrome}

Activation of the hypothalamic-pituitary-adrenal axis by AVP in chronic psychosocial stress is one of the mediators associated with insulin resistance, diabetes mellitus, obesity and metabolic syndrome $(16,48)$. AVP directly stimulates the secretion of cortisol by activating V1a receptors, which interferes with insulin activity, stimulates glucagon secretion and glycogenolysis. This process subsequently leads to an increase in blood glucose. AVP also by activating the $\mathrm{V} 1 \mathrm{~b}$ receptors on the chromaffin cells in the adrenal medulla increases epinephrine which also contributes to the development of hyperglycemia through glycogenolysis in the liver (48). Raised AVP, as a result of resistance of AVP to V1a receptor, might also contribute to insulin resistance and development of diabetes mellitus by stimulation of V1b receptor (16). Therefore, copeptin could be a new potential biomarker of insulin resistance and diabetes mellitus.

Copeptin is also associated with several components of metabolic syndrome including obesity, dyslipidemia, elevated concentration of triglycerides and low HDL-cholesterol. The association of copeptin with higher triglyceride concentration may be secondary to increased hepatic triglyceride synthesis due to glucocorticoids, glucagon and epinephrine released under stress (all of which are regulated by AVP) (48). Enhörning et al. reported that elevated copeptin concentration at baseline predicted the incidence of diabetes mellitus and abdominal obesity during a long-term follow-up of 15.8 years on average. The association between copeptin at baseline and the incidence of diabetes mellitus is independent of the incidence of $a b-$ dominal obesity and vice versa, so it is possible that AVP independently triggers two different pathways leading to diabetes mellitus and abdominal obesity. Despite this, there is the possibility that a primary elevation of AVP by increasing abdominal fat deposition leads to the development of diabetes mellitus (49).

\section{Copeptin and central nervous system diseases}

In intracerebral hemorrhage (ICH) formation of edema in the brain indicates an unfavorable out- come. It has been shown that blockade of AVP receptors reduces brain edema. This suggests that AVP has an important role in the formation of brain edema $(17,50,51)$. Thus, measurement of copeptin can indicate existing or developing brain edema which can help in identifying patients with increased risk of edema formation (50). Also, after $\mathrm{ICH}$ copeptin concentration in plasma is significantly increased, reflecting the severity of hemorrhagic damage and predicting long-term clinical outcome. Copeptin also helps to identify patients with risk of early neurological deterioration and correlates with hematoma volume, which is directly associated with clinical severity and outcome after ICH (50-52). Other biomarkers ( $D$-dimer, glutamate, matrix metalloproteinases and protein $\mathrm{S100b)}$ can also predict early neurological deterioration and mortality in patients with $\mathrm{ICH}$ by way of different pathophysiological processes. Therefore, it is advised that prognostic assessments and decisions about management of ICH rely on few parameters where copeptin as a new prognostic biomarker is used in combination with other biomarkers (50). Copeptin, unlike the other brain biomarkers, is directly secreted into the systemic circulation. This fact gives relevance to copeptin measurement in ICH (17). In other conditions, such as ischemic stroke, aneurysmal subarachnoid hemorrhage and head injury, copeptin concentration is elevated as well (53). In this group of patients high copeptin concentration in peripheral blood is associated with mortality and poor neurologic outcome (51). Yu et al. reported that copeptin increases with severity of brain injury and therefore, its measurements after brain injury provides an opportunity to distinguish patients with a one-year good or poor outcome (17).

\section{Conclusion}

Copeptin, as a biomarker released into the circulation under endogenous stress, could be a potentially promising biomarker in diagnosis of various diseases and prediction of functional outcomes. Since it is not specific to a certain disease, copeptin could be used as an adjunct with more specific biomarkers where it may increase diagnostic accu- 
racy and aid clinicians in making better diagnostic judgements. However, copeptin is still in its infancy and more research is needed in order to prove its clinical usefulness.

\section{Potential conflict of interest}

None declared.

\section{References}

1. Jochberger S, Morgenthaler NG, Mayr VD, Luckner G, Wenzel V, Ulmer H, et al. Copeptin and arginine vasopressin concentrations in critically ill patients. J Clin Endocrinol Metab 2006;91:4381-6. http://dx.doi.org/10.1210/jc.2005-2830.

2. Katan M, Morgenthaler NG, Dixit KCS, Rutishauser J, Brabant GE, Müller B, Christ-Crain M. Anterior and posterior pituitary function testing with simultaneous insulin tolerance test and a novel copeptin assay. J Clin Endocrinol Metab 2007;92:2640-3. http://dx.doi.org/10.1210/jc.2006-2046.

3. Szinnai G, Morgenthaler NG, Berneis K, Struck J, Müller B, Keller U, Christ-Crain M. Changes in plasma copeptin, the cterminal portion of arginine vasopressin during water deprivation and excess in healthy subjects. $J$ Clin Endocrinol Metab 2007;92:3973-8. http://dx.doi.org/10.1210/jc.20070232.

4. Jochberger S, Luckner G, Mayr VD, Wenzel V, Morgenthaler NG, Friesenecker BE, et al. Course of vasopressin and copeptin plasma concentrations in a patient with severe septic shock. Anaesth Intensive Care 2006;34:498-500.

5. Morgenthaler NG, Struck J, Jochberger S, Dünser MW. Copeptin: clinical use of a new biomarker. Trends Endocrinol Metab 2008;19:43-9. http://dx.doi.org/10.1016/j. tem.2007.11.001.

6. Struck J, Morgenthaler NG, Bergmann A. Copeptin, a stable peptide derived from the vasopressin precursor, is elevated in serum of sepsis patients. Peptides 2005;26:2500-4. http://dx.doi.org/10.1016/j.peptides.2005.04.019.

7. Balanescu S, Kopp P, Gaskill MB, Morgenthaler NG, Schindler $C$, Rutishauser J. Correlation of plasma copeptin and vasopressin concentrations in hypo-, iso-, and hyperosmolar states. J Clin Endocrinol Metab 2011;96:1046-52. http:// dx.doi.org/10.1210/jc.2010-2499.

8. Katan M, Müller B, Christ-Crain M. Copeptin: a new and promising diagnostic and prognostic marker. Crit Care 2008;12:117. http://dx.doi.org/10.1186/cc6799.

9. Khan SQ, Dhillon OS, O'Brien RJ, Struck J, Quinn PA, Morgenthaler NG, et al. C-terminal provasopressin (copeptin) as a novel and prognostic marker in acute myocardial infarction: Leicester acute myocardial infarction peptide (LAMP) study. Circulation 2007;115:2103-10. http://dx.doi. org/10.1161/CIRCULATIONAHA.106.685503.

10. Hoorn EJ, van Wolfswinkel ME, Hesselink DA, de Rijke YB, Koelewijn $R$, van Hellemond JJ, van Genderen PJJ. Hyponatraemia in imported malaria: the pathophysiological role of vasopressin. Malar J 2012;11:26. http://dx.doi. org/10.1186/1475-2875-11-26.
11. Voors $A A$, von Haehling S, Anker SD, Hillege HL, Struck J, Hartmann $O$, et al. C-terminal provasopressin (copeptin) is a strong prognostic marker in patients with heart failure after an acute myocardial infarction: results from the $O P$ TIMAAL study. Eur Heart J 2009;30:1187-94. http://dx.doi. org/10.1093/eurheartj/ehp098.

12. Bhandari SS, Loke I, Davies JE, Squire IB, Struck J, Ng LL. Gender and renal function influence plasma levels of copeptin in healthy individuals. Clin Sci (Lond) 2009;116:25763. $h t t p: / / d x . d o i . o r g / 10.1042 / C S 20080140$.

13. Lippi G, Plebani M, Di Somma S, Monzani V, Tubaro M, Volpe $M$, et al. Considerations for early acute myocardial infarction rule-out for emergency department chest pain patients: the case of copeptin. Clin Chem Lab Med 2012;50:243-53. http://dx.doi.org/10.1515/cclm-2011-0845.

14. Egashira N, Mishima K, Iwasaki K, Oishi R, Fujiwara M. New topics in vasopressin receptors and approach to novel drugs: Role of the vasopressin receptor in psychological and cognitive functions. J Pharmacol Sci 2009;109:44-9. http:// dx.doi.org/10.1254/jphs.08R14FM.

15. Seligman R, Seligman BGS, Teixeira PJZ. Comparing the accuracy of predictors of mortality in ventilator-associated pneumonia. J Bras Pneumol 2011;37:495-503. http:// dx.doi.org/10.1590/S1806-37132011000400012.

16. Enhörning $S$, Wang TJ, Nilsson PM, Almgren P, Hedblad $B$, Berglund $G$, et al. Plasma copeptin and the risk of diabetes mellitus. Circulation 2010;121:2102-8. http://dx.doi. org/10.1161/CIRCULATIONAHA.109.909663.

17. Yu GF, Huang $Q$, Dai WM, Jie YQ, Fan XF, Wu A, et al. Prognostic value of copeptin: One-year outcome in patients with traumatic brain injury. Peptides 2012;33:164-9. http:// dx.doi.org/10.1016/j.peptides.2011.11.017.

18. Günebakmaz Ö, Celik A, Inanc MT, Duran $M$, Karakaya E, Tulmac $M$, et al. Copeptin level and copeptin response to percutaneous balloon mitral valvuloplasty in mitral stenosis. Cardiology 2011;120:221-6. http://dx.doi. org/10.1159/000335888.

19. Stoiser B, Mörtl D, Hülsmann M, Berger R, Struck J, Morgenthaler NG, et al. Copeptin, a fragment of the vasopressin precursor, as a novel predictor of outcome in heart failure. Eur J Clin Invest 2006;36:771-8. http://dx.doi.org/10.1111/ j.1365-2362.2006.01724.x.

20. Nickel $\mathrm{CH}$, Bingisser R, Morgenthaler NG. The role of copeptin as a diagnostic and prognostic biomarker for risk stratification in the emergency department. BMCMed 2012;10:7. http://dx.doi.org/10.1186/1741-7015-10-7.

21. Morgenthaler NG, Struck J, Alonso C, Bergmann A. Assay for the measurement of copeptin, a stable peptide derived from the precursor of vasopressin. Clin Chem 2006;52:112-9. http://dx.doi.org/10.1373/clinchem.2005.060038.

22. Robertson GL, Mahr EA, Athar S, Sinha T. Development and clinical application of a new method for the radioimmunoassay of arginine vasopressin in human plasma. J Clin Invest 1973;52:2340-52. http://dx.doi.org/10.1172/ JCI107423. 
23. Hernández-Romero $D$, García-Salas JM, López-Cuenca $A$ Pérez-Berbel P, Puche C, Casas T, et al. High-sensitivity troponin T and copeptin in non-ST acute coronary syndromes: Implications for prognosis and role of hsTnT and copeptin in non-STEACS. Scientific World Journal 2012;2012:578616.

24. Ray P, Charpentier S, Chenevier-Gobeaux C, Reichlin T, Twerenbold $R$, Claessens $Y E$, et al. Combined copeptin and troponin to rule out myocardial infarction in patients with chest pain and a history of coronary artery disease. Am J Emerg Med 2012;30:440-8. http://dx.doi.org/10.1016/j. ajem.2011.12.008.

25. Gu JL, Voors AA, Zijlstra F, Hillege HL, Struck J, Masson S, et al. Comparison of the temporal release pattern of copeptin with conventional biomarkers in acute myocardial infarction. Clin Res Cardiol 2011;100:1069-76. http://dx.doi. org/10.1007/s00392-011-0343-y.

26. von Haehling S, Papassotiriou J, Morgenthaler NG, Hartmann $O$, Doehner W, Stellos K, et al. Copeptin as a prognostic factor for major adverse cardiovascular events in patients with coronary artery disease. Int J Cardiol 2012;162:27-32. http://dx.doi.org/10.1016/j.ijcard.2011.12.105.

27. Reichlin T, Hochholzer W, Stelzig C, Laule K, Freidank H, Morgenthaler NG, et al. Incremental value of copeptin for rapid rule out of acute myocardial infarction. J Am Coll Cardiol 2009;54:60-8. http://dx.doi.org/10.1016/j.jacc.2009.01.076.

28. Meune C, Zuily S, Wahbi K, Claessens YE, Weber S, Chenevier-Gobeaux C. Combination of copeptin and high-sensitivity cardiac troponin $T$ assay in unstable angina and non-ST-segment elevation myocardial infarction: $A$ pilot study. Arch Cardiovasc Dis 2011;104:4-10. http://dx.doi. org/10.1016/j.acvd.2010.11.002.

29. Lotze U, Lemm H, Heyer A, Müller K. Combined determination of highly sensitive troponin T and copeptin for early exclusion of acute myocardial infarction: first experience in an emergency department of a general hospital. Vasc Health Risk Manag 2011;7:509-15. http://dx.doi.org/10.2147/ VHRM.S21753.

30. Keller T, Tzikas S, Zeller T, Czyz E, Lillpopp L, Ojeda FM, et al. Copeptin improves early diagnosis of acute myocardial infarction. J Am Coll Cardiol 2010;55:2096-106. http://dx.doi. org/10.1016/j.jacc.2010.01.029.

31. Alehagen U, Dahlström U, Rehfeld JF, Goetze JP. Association of copeptin and $\mathrm{N}$-terminal proBNP concentrations with risk of cardiovascular death in older patients with symptoms of heart failure. JAMA 2011;305:2088-95. http:// dx.doi.org/10.1001/jama.2011.666.

32. Neuhold S, Huelsmann M, Strunk G, Struck J, Adlbrecht C, Gouya $G$, et al. Prognostic value of emerging neurohormones in chronic heart failure during optimization of heart failure-specific therapy. Clin Chem 2010;56:121-6. http:// dx.doi.org/10.1373/clinchem.2009.125856.

33. Neuhold S, Huelsmann M, Strunk G, Stoiser B, Struck J, Morgenthaler NG, et al. Comparison of copeptin, B-type natriuretic peptide, and amino-terminal pro-B-type natriuretic peptide in patients with chronic heart failure. $J \mathrm{Am}$ Coll Cardiol 2008;52:266-72. http://dx.doi.org/10.1016/j. jacc.2008.03.050.
34. Fenske W, Störk S, Blechschmidt A, Maier SGK, Morgenthaler NG, Allolio B. Copeptin in the differential diagnosis of hyponatremia. J Clin Endocrinol Metab 2009;94:123-9. http://dx.doi.org/10.1210/jc.2008-1426.

35. Nigro N, Müller B, Morgenthaler NG, Fluri F, Schuetz $P, N e-$ idert $S$, et al. The use of copeptin, the stable peptide of the vasopressin precursor, in the differential diagnosis of sodium imbalance in patients with acute diseases. Swiss Med Wkly 2011;141:w13270.

36. Jochberger S, Dörler J, Luckner G, Mayr VD, Wenzel V, Ulmer $H$, et al. The vasopressin and copeptin response to infection, severe sepsis, and septic shock. Crit Care Med 2009;37:476 82. http://dx.doi.org/10.1097/CCM.0b013e3181957532.

37. Lesur O, Roussy JF, Chagnon F, Gallo-Payet N, Dumaine R, Sarret $P$, et al. Proven infection-related sepsis induces a differential stress response early after ICU admission. Crit Care 2010;14:R131. http://dx.doi.org/10.1186/cc9102.

38. Boeck L, Eggimann P, Smyrnios N, Pargger H, Thakkar N, Siegemund $M$, et al. The Sequential Organ Failure Assessment score and copeptin for predicting survival in ventilator-associated pneumonia. J Crit Care 2012;27:523. http:// dx.doi.org/10.1016/j.jcrc.2011.07.081.

39. Müller B, Morgenthaler N, Stolz D, Schuetz P, Müller C, Bingisser $R$, et al. Circulating levels of copeptin, a novel biomarker, in lower respiratory tract infections. Eur J Clin Invest 2007;37:145-52. http://dx.doi.org/10.1111/j.13652362.2007.01762.x.

40. Krüger S, Ewig S, Kunde J, Hanschmann A, Marre R, Suttorp $N$, Welte T. C-terminal provasopressin (copeptin) in patients with community-acquired pneumonia-influence of antibiotic pre-treatment: results from the German competence network CAPNETZ. J Antimicrob Chemother 2009;64:15962. http://dx.doi.org/10.1093/jac/dkp148.

41. Krüger S, Ewig S, Giersdorf S, Hartmann O, Suttorp N, Welte T; CAPNETZ Study Group. Cardiovascular and inflammatory biomarkers to predict short- and long-term survival in community-acquired pneumonia: Results from the German Competence Network, CAPNETZ. Am J Respir Crit Care Med 2010;182:1426-34. http://dx.doi.org/10.1164/ rccm.201003-04150C.

42. Seligman R, Papassotiriou J, Morgenthaler NG, Meisner $M$, Teixeira PJZ. Copeptin, a novel prognostic biomarker in ventilator-associated pneumonia. Crit Care 2008;12:R11. http://dx.doi.org/10.1186/cc6780.

43. Masiá M, Papassotiriou J, Morgenthaler NG, Hernández I, Shum C, Gutiérrez F. Midregional Pro-A-type natriuretic peptide and carboxy-terminal provasopressin may predict prognosis in community-acquired pneumonia. Clin Chem 2007;53:2193-201. http://dx.doi.org/10.1373/ clinchem.2007.085688.

44. Stolz D, Christ-Crain M, Morgenthaler NG, Leuppi J, Miedinger D, Bingisser $R$, et al. Copeptin, C-reactive protein, and procalcitonin as prognostic biomarkers in acute exa cerbation of COPD. Chest 2007;131:1058-67. http://dx.doi. org/10.1378/chest.06-2336. 
45. Potocki M, Breidthardt $T$, Mueller A, Reichlin T, Socrates $T$, Arenja $N$, et al. Copeptin and risk stratification in patients with acute dyspnea. Crit Care 2010;14:R213. http://dx.doi. org/10.1186/cc9336.

46. Torgersen C, Luckner G, Morgenthaler NG, Jochberger S, Schmittinger $C A$, Wenzel $V$, et al. Plasma copeptin levels before and during exogenous arginine vasopressin infusion in patients with advanced vasodilatory shock. Minerva Anestesiol 2010;76:905-12.

47. Meijer E, Bakker SJL, van der Jagt EJ, Navis G, de Jong PE, Struck J, Gansevoort RT. Copeptin, a surrogate marker of vasopressin, is associated with disease severity in autosomal dominant polycystic kidney disease. Clin J Am Soc Nephrol 2011;6:361-8. http://dx.doi.org/10.2215/CJN.04560510.

48. Saleem $U$, Khaleghi $M$, Morgenthaler NG, Bergmann $A$, Struck J, Mosley THJ, Kullo IJ. Plasma carboxy-terminal provasopressin (copeptin): A novel marker of insulin resistance and metabolic syndrome. J Clin Endocrinol Metab 2009;94:2558-64. http://dx.doi.org/10.1210/jc.2008-2278.

49. Enhörning S, Bankir L, Bouby N, Struck J, Hedblad B, Persson $M$, et al. Copeptin, a marker of vasopressin, in abdominal obesity, diabetes and microalbuminuria: the prospective Malmö Diet and Cancer Study cardiovascular cohort. Int J Obes (Lond) 2013;37:598-603. http://dx.doi.org/10.1038/ ijo.2012.88.
50. Zweifel C, Katan M, Schuetz P, Siegemund M, Morgenthaler NG, Merlo A, et al. Copeptin is associated with mortality and outcome in patients with acute intracerebral hemorrhage. BMC Neurol 2010;10:34. http://dx.doi.org/10.1186/14712377-10-34.

51. Zhang $X, L u X M$, Huang $L F$, Ye $H$. Copeptin is associated with one-year mortality and functional outcome in patients with acute spontaneous basal ganglia hemorrhage. Peptides 2012;33:336-41. http://dx.doi.org/10.1016/j. peptides.2012.01.011.

52. Dong $X Q$, Huang $M, Y u W H$, Zhang $Z Y$, Zhu $Q$, Che $Z H$, et al. Change in plasma copeptin level after acute spontaneous basal ganglia hemorrhage. Peptides 2011;32:253-7. http:// dx.doi.org/10.1016/j.peptides.2010.11.021.

53. Zhu XD, Chen JS, Zhou F, Liu QC, Chen G, Zhang JM. Detection of copeptin in peripheral blood of patients with aneurysmal subarachnoid hemorrhage. Crit Care 2011;15:R288. http://dx.doi.org/10.1186/cc10575. 